\title{
Doing gender and development: understanding empowerment and local gender relations
}

\author{
Joanne Sharp*, John Briggs*, Hoda Yacoubt and \\ Nabila Hamedt
}

\begin{abstract}
A major dilemma in Gender and Development (GAD) work is why it is that sometimes women may feel better off colluding with gendered structures that ensure their continued subordination rather than seeking approaches that will allow them to break free of this. Kandiyoti (1988 Gender and Society 2 274-90) has identified this apparent collusion as 'patriarchal bargains', which offer women greater advantages than they perceive can be achieved by challenging the prevailing order. Such women are therefore reluctant to engage in empowering activities that may challenge their gendered bargain. This paper explains this dilemma in the context of GAD work undertaken with Bedouin women in Southern Egypt.
\end{abstract}

key words empowerment gender and development patriarchal bargain sheep production

\author{
*Department of Geography and Geomatics, University of Glasgow, Glasgow G12 8QQ \\ email: jsharp@geog.gla.ac.uk \\ tUnit for Environmental Studies and Development, South Valley University, Aswan, Egypt \\ revised manuscript received 16 January 2003
}

\section{Introduction}

Gender and Development (GAD) projects have struggled to be sensitive to local contexts in order not to impose universal or Westernized views of development or gender identities on diverse communities. However, this context dependency has meant that sometimes GAD projects come up against understandings of women's roles and identities that contradict the long-term goals of women's empowerment which is so central to this approach. In some places, women perceive benefits from what Kandiyoti (1988) has called 'patriarchal bargains' that are in excess of any advantages that women perceive can be achieved by challenging the prevailing order. Women who adopt this strategy ${ }^{1}$ are therefore reluctant to engage in activities that may challenge their gendered bargain. This paper examines such a situation, amongst women in both the desert and in market places in Upper Egypt. Here, although some poorer women are willing to embrace opportunities for economic empowerment, many others are not. The paper will attempt to account for this reluctance, and discuss the implications for GAD work amongst such communities.

\section{Empowerment}

With the recent recognition that large-scale, topdown approaches to development have generally resulted in failure, increasing numbers of academics and development practitioners have sought solutions to the 'development impasse' (Leys 1996) that work from the bottom up, involving the target populations of development in their own programmes (Parpart 2002, 340). Rowlands (1997) points out that people from across the political spectrum claim now to support the concept of 'empowerment' as part of this decentring of decisionmaking power. It appears that empowerment 'has become a popular, largely unquestioned "goal"' (Parpart 2002 , 338). This apparently universal appeal is due 
to the vagueness of the concept: it is one that common sense insists is a good thing, but quite what the term 'empowerment' means, or how it is achieved, is more complex and contested. Much of this fluidity of meaning can be traced to the differing definitions of power that different understandings of empowerment depend upon. After all, to be empowered 'is to be invested with power' (Peake 1999). For many development organizations, power is defined as 'power over', meaning that, in the case of GAD, women will gain power at the expense of men. This view suggests that women 'should be empowered to participate within the economic and political structures of society occupying positions of power in terms of political and economic decisionmaking' (Rowlands 1997, 11). This reformist approach accepts current social structures rather than seeking transformation. Like earlier Women in Development (WID) approaches, this accepts the way in which decisions are made and the processes through which resources are allocated, but considers that women should be given positions in the hierarchy of power to ensure equality.

Others look at 'power to', which has empowerment as the ability to act in particular ways. What is important about this approach is that it does not produce a zero-sum game where women's advantage is men's disadvantage, but that the increased empowerment of women will improve the community as a whole. Increased ability to act, whether in matters to do with market production or household reproduction, will have a positive effect on all members of the group. Indeed, there is often the assumption that development is the same thing as empowerment, so that the improvement of economic position, such as the involvement of women in formal economic spheres, will empower women. However, there are other possible outcomes. Bryceson (1995) argues that there is an expectation that providing women with the means to generate a cash income will improve their status within their families and more broadly within the community. As she puts it,

Income-generating projects have dominated. The belief that women can begin to gain equality with men by earning cash 'outside the household' has been implicit or explicit in most approaches and project designs. (Bryceson 1995, 205)

However, she continues, there is no empirical evidence which necessarily supports this position.
Furthermore, it misses the point of the problem faced by many rural African women. For many, the problem is primarily one of time. Pressures to generate cash, in addition to other work, can be interpreted as a further (and, in many cases, unmanageable) burden:

\footnotetext{
How can women participate in increased commodity production in addition to their activities in food production, household maintenance and childcare? ... women's over-booked working day is the major stumbling block to their involvement in what donors perceive as 'status-enhancing' productive activities. (Bryceson 1995, 209; see also Grown et al. 2000)
}

A number of Third World feminists have highlighted that 'empowerment', thus articulated unreflexively from the point of view of a middleclass dominated feminism, is a dubious achievement (see Mohanty et al. 1991). Very similar sentiments have been expressed by women in post-communist Eastern Europe where the history of socialism meant that all women were expected to work in addition to carry out their domestic responsibilities. Their writings have been critical of Western feminists for assuming the emancipatory value of leaving the household to find work (see the essays in Funk and Mueller 1993; Jankowska 1991; Einhorn 1993). For many women, the issue of empowerment does not revolve around the ability to leave the home to be admitted into the labour force; for them their lifeworlds have always spanned both public and private spaces. Women's rights in the work force simply mean a double burden for women who must tend to responsibilities for household reproduction after a day at work. What might appear as empowerment might simply add extra burdens to a woman's work day.

Rowlands (1997) points out that there are other forms of empowerment based upon understandings of power that are less tangible. From Lukes (1974) comes the idea that the most effective operations of power are those which prevent people from even thinking about how the world might operate otherwise. Foucault's $(1977,1980)$ influential analysis of the workings of power through the discourses which construct notions of active selfhood are similarly effective here. Thus, for many involved in empowering women's communities, the most important form of empowerment involves 'power from within' (Rowlands 1997, 111) where self-perceptions and understandings are challenged in such a way as to enable women to think of alternative ways of existing, so generating a 
belief in their own abilities to have some role in the enactment of this change. Empowerment becomes the generation of a sense of effective agency. It is the process through which women decide to act that is so central here. For this understanding of power then, the process of gaining empowerment, of considering oneself a capable agent, is as much an aim of the process and the material end result (women's credit schemes, education etc.) of any particular project.

Thus, more recent formulations of the role of men and women in the development process, especially GAD, accept that it is not just the formal mechanisms of decisionmaking that can hinder improvements in the standard of living of women. Less tangible elements of cultural and social organization may also directly impact upon women's lives, not only hindering their decisionmaking capabilities, but ensuring that women do not even consider that they could improve their situation; they do not think that alternatives are possible. Much of this internalization of things-as-they-are is the result of processes of socialization that reinforce they way things should be. Here,

[e]mpowerment is thus more than participation in decisionmaking; it must also include the processes that lead people to perceive themselves as able and entitled to make decisions. (Rowlands 1997, 14, emphasis in original)

This implies a potentially important role for agents from outside the communities involved, a contentious suggestion. One of the main dilemmas currently facing feminist geographers researching development is the contradiction between the desire to recognize the diversity of experiences of women (involving issues of 'race', ethnicity, caste and class, for instance) (see Mohanty 1988; Mohanty et al. 1991), without falling back on a relativist position of 'different places, different voices' which 'evades the challenge of theorising gender and development' (Pearson and Jackson 1998, 13; see also Kent 1995). Part of this shift is in response to criticism from Third World feminists highlighting the often uncritical use of Western feminist concepts in development, as if these ideas were universal rather than specifically Western. Mohanty (1988) has argued that too often Western feminists see Third World women as nothing more than victims of male control or of traditional culture, so reflecting back a progressive image of the nature of Western feminism and holding up the model of emancipated Western woman as the goal for all women. Alternatively, there has been a desire on the part of Western feminists to hold up rural African women as an ideal of autonomous female production (Bryceson 1995, 202). In neither case, Mohanty (1988) continues, is there an attempt to understand the history of different communities.

Such critiques have left many Western feminists reluctant to engage in research with Third World women participants (see the discussion in Radcliffe 1994). This has meant that often the social relations of gender 'are labelled as falling into the realm of culture and strong advocacy for a rethinking of gender relations would be seen as unwarranted "cultural interference"' (Rathgeber 1995, 207), although social relations based around class and income, for instance, are seen as open for criticism (Chant and Gutmann 2000, 20). This discussion of cultural imperialism is undoubtedly vital in ensuring that feminism does not go the way of other discourses of development in assuming a colonizing mentality which suggests that the outside expert is always right. However, this does not mean that feminists need to abandon their aims of the emancipation of women:

Women need to be free to act from their own analysis and priorities and not be manipulated by outsiders; yet the restrictions of internalised oppression, which limit women's options, must be challenged. (Rowlands 1997, 134)

Thus, without imposing outside views on a population of women, 'a methodology should be adopted that will help women to perceive the limitations that they place on themselves' (Rowlands 1997, 134). Only when the critique of current conditions comes from the women themselves, then, can development processes effectively challenge the relations of patriarchal domination and achieve empowerment (in whatever form).

In attempting to adopt empowerment as part of a GAD strategy, it is also necessary to take seriously the role of men. Although the vast majority of positions of power are occupied by men, this does not mean that all men occupy positions of power. Many men are marginalized by it. It is important, therefore, not to assume that all men are direct beneficiaries of current social arrangements, nor that they would be hostile to any change to it. It is also important not to assume that women feel hostility towards men, even in situations where it seems clear that gender relations are exploitative of women. As Cornwall points out, 
Those relationships, experiences and identities that fall outside the narrow frame set by oppressive heterosexual 'gender relations' tend to be disregarded. In the midst of all this, there is no space at all for men's experiences of powerlessness, love or dependency in their relationships with women, nor for relations between men that are equally inflected with gender. (Cornwall 2000, 20)

Finally, it is inappropriate to expect women to shoulder all of the responsibility (and additional workload) of change. As Chant and Gutmann point out, apart

from the fact that excluding men gives them little chance to challenge the constructions imposed upon them, dealing with 'the problem' through women, negates the self-reflection on the part of men that might be crucial to change in gender relations. (Chant and Gutmann 2000, 24)

The concerns of this paper emerge from a project which aimed to investigate the role of Bedouin women in the production of small livestock in the Eastern Desert of Southern Egypt, and to explore the potential roles of women in marketing sheep and goat products in regional markets. Previous research in the area has noted the primary economic significance of small livestock rearing and the male domination of this sector (Briggs 1995). The project being discussed here sought to build on these earlier results to understand the actual and potential roles that women do and could play in this sector. Research was funded by the UK Department for International Development in the form of a one-year Gender and Development small grant. Although predominantly a research project, an additional aim was to work with Bedouin women to improve the quality of their livestock through the development of small-scale agriculture producing small amounts of fodder as a feed supplement. Thus, it was hoped that a longer-term aim of the project could be an empowerment of the women involved through an increased confidence in their own abilities and respect from others for their enhanced contribution to the household budget.

The research project was carried out with a Bedouin community in the Wadi Allaqi area of south-eastern Egypt between April 2000 and March 2001. The research team comprised a number of male and female (non-Bedouin) Egyptian and UK researchers, both postgraduate students and staff members. The Egyptian department, the Unit for Environmental Studies and Development at the University of the South Valley in Aswan, has a field centre and agricultural research centre in Wadi Allaqi and has worked in the area (with and without the involvement of the Bedouin) for more than 15 years. The current research project is the first where women were consulted about their own perspectives; nevertheless, visits were not considered unusual due to this history of contact. Moreover, the visits were not only concerned with the research topics but involved news of relatives and the delivery of produce from Aswan by the research team. Research was carried out in the form of regular discussions with the Bedouin. As is conventional for non-family guests, the male researchers were met by Bedouin men in the designated guest areas, which are at some distance from the private spaces of the household. The female researchers were taken into this domestic space, where they could talk with the Bedouin women without the presence of men.

The methodological approach adopted was one which endeavoured to allow Bedouin women and men to set the agenda and which facilitated the inclusion of their opinions and arguments to as great an extent as possible. The methodology was based on a series of monthly in-depth conversational interviews, and, as far as possible, the atmosphere of these meetings was one of a conversation. In each case, two or three researchers would visit each group of women to ensure a more 'natural' form of conversation, rather than something more like a formal interview. Bedouin do not like tape recordings and are even highly wary of note taking in their presence, and so discussion is unrecorded until a later time. Having multiple research team members present ensures that most of the details of the conversations can be remembered later. This, in addition to the fact that most of the conversations involved a number of women, often more than one talking at once, has meant that our inclusion of Bedouin women's voices in this research project is not in the way of direct quotation, but compiled from later recollection of themes and examples raised during the conversations. The unfortunate consequence of this is that the Bedouin women's voices cannot be heard directly in the written account of this work but must be mediated through the researchers' memories and words. As the number of meetings for each of the groups progressed during the year, so did the degree of trust and even friendship. This allowed for the development of ideas to take place during the year of the study. 
The project team visited five main focus groups on a monthly basis over the period of the study. The groups were selected from each of the three main Ababda clans resident in downstream Wadi Allaqi, each of which has a clearly defined geographic territory in Wadi Allaqi. Unfortunately, one of the groups left the area about half way through the year to migrate to another location about 150 kilometres away which had better grazing resources, but a considerable amount of material was gained before their departure. The visits to the groups typically lasted at least one hour on each occasion, although sometimes significantly longer. Typically, there would be several women at each location, although we visited the 'key' respondent present on each occasion whenever possible. As the conversations took place in the women's space in the settlement, frequently women continued with their domestic tasks whilst talking with us, and especially so as the team members became better known to the Bedouin women respondents over the year.

As a further part of the project, we also interviewed men and women buying and selling livestock in regional markets in order to understand the roles that women could adopt in this space. In addition, we collected information on different types of small livestock on sale at the markets, and particularly on which feeds ensured the best price. This information was passed onto the Bedouin women. We looked at markets serving different scales of communities, visiting three markets on regular occasions, all located in the Nile Valley, at Daraw and Aswan (both livestock markets) and at the Aswan meat market. These were very different research environments and experiences from those involving the Bedouin focus groups in the desert, as these markets comprised clearly demarcated and defined spaces, and they were predominantly male spaces. This provided different methodological challenges, as encounters here were more interviews than conversations, hence there was less opportunity for cross-checking.

\section{The economic and social context for Bedouin women in the Eastern Desert}

The study area is located in the downstream part of Wadi Allaqi, located about 180 kilometres to the south of Aswan (Figure 1). Wadi Allaqi is the main wadi (dry valley) of the southern part of the Eastern Desert of Egypt, and extends over 150 kilometres south-eastwards into the northern Sudan. The climate is hyperarid, with rainfall hardly ever being experienced in the downstream part of the wadi, the area under study, although rainfall events upstream in the Red Sea Hills can result in occasional surface flows along the wadi floor downstream (there have been two such events in the last 15 years). However, this is a dynamic environment. The resources traditionally available to Bedouin in this area changed markedly with the construction of the Aswan High Dam during the 1960s, and the subsequent inundation by the High Dam Lake (Lake Nasser). Some 70-80 kilometres of Wadi Allaqi became permanently inundated as an arm of Lake Nasser. Superimposed on these longerterm lake level changes, there is also a well-defined pattern of annual change. Within each year, the lake level peaks in November or December before dropping typically by up to 6-8 metres to its lowest level in July. During these annual lake retreats, grazing opportunities along the emergent lakeshore present themselves for livestock.

The Bedouin have traditionally been a highly mobile group, moving all their belongings to follow seasonal pastures in the hyper-arid environment of the Eastern Desert. With the establishment of Lake Nasser, the Bedouin have become more sedentary. Women no longer migrate with the men but have settled near to the water supply of the lake, moving only to follow shore as it moves with lake level fluctuation. ${ }^{2}$ The Wadi Allaqi Bedouin practice Islam and women are to avoid meeting men who are not from their immediate family. The spatial arrangement of the household provides a women's area away from the place where guests are met. The beit bersh, the traditional tents used by Bedouin in this area, of extended family groups are arranged between a few metres and a few hundred metres from one another. Each extended household is dominated by a senior patriarch who makes major household decisions, while day-to-day decisionmaking is left to the individual households. In the past, the entire household would move to follow resources. Now, only men take the household herds to distant parts of the desert in search of grazing, and to trade in markets such as Aswan. Women are not mobile and must be accompanied by a male relative on their rare visits to town (in case of illness or an important family occasion). ${ }^{3}$

The attractions of downstream Wadi Allaqi for the Bedouin communities living there are both the reliable supply of water from the lake and the 


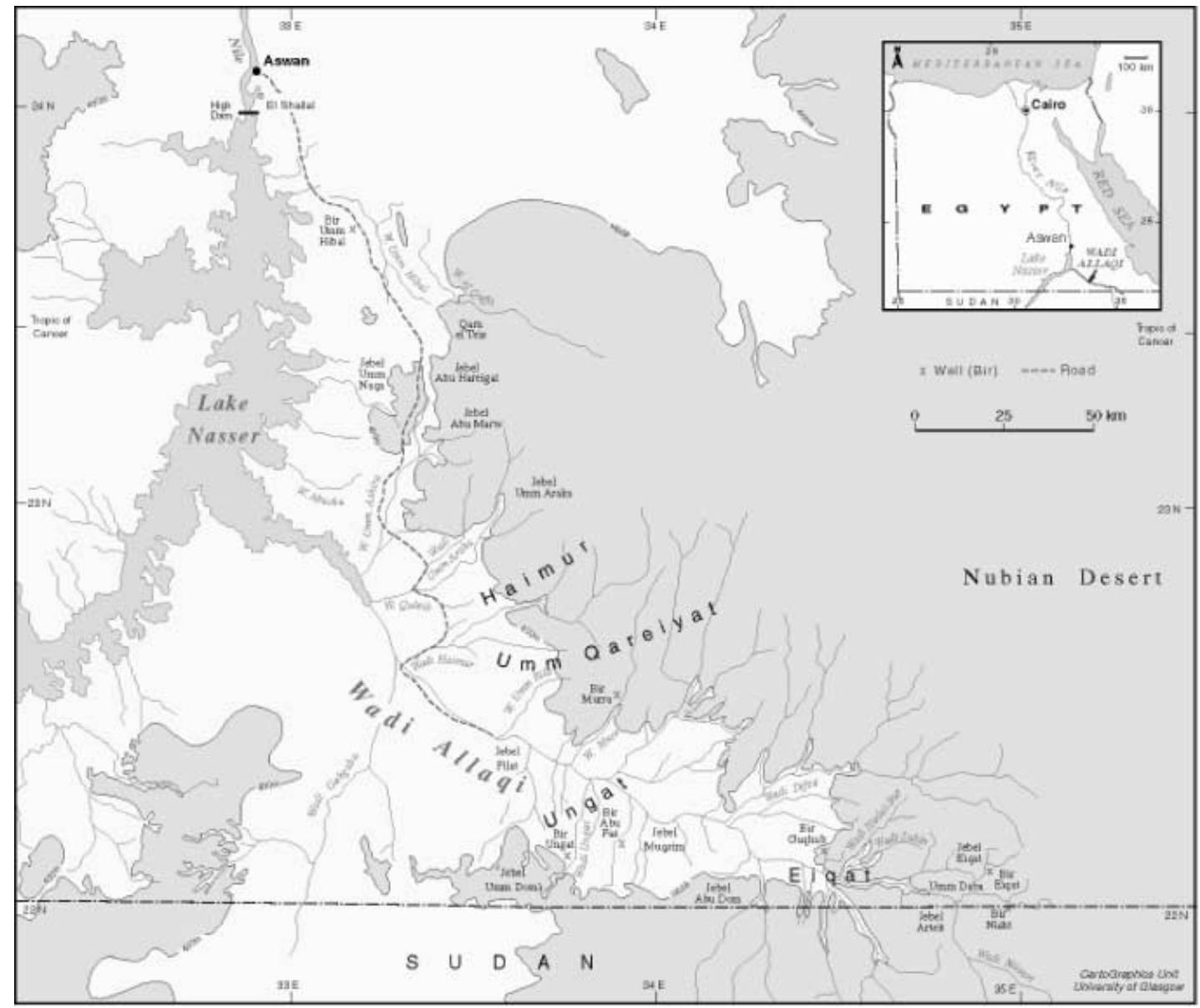

Figure 1 Location of Wadi Allaqi

availability of vegetation resources for livestock grazing that follow after the annual inundation. However, the latter are not quite as productive as might first seem. Each year, as the annual lake level recedes (from December until about JulyAugust), grasses and herbs grow on the emergent lakeshore, but they are not always particularly abundant. Hence, although in many ways an attractive area for Bedouin settlement, many of the families still retain an important nomadic component to their economic activities. This entails taking sheep into upstream Wadi Allaqi or, rather less frequently, the Red Sea Hills, for winter grazing (thus providing some relief for grazing resources in the lakeshore area itself); producing charcoal in the same upstream and hill areas; grazing camels in areas outside Wadi Allaqi; and collecting medicinal plants from a number of locations in the Eastern Desert (Briggs 1995). The male Bedouin of downstream Wadi Allaqi are, as yet, by no means fully sedentarized.

It is within the context of these resource opportunities that the economic system of the area has evolved, and, in particular, this new water resource has provided a new opportunity for the Bedouin of the area (Briggs et al. 1993). Members of three Ababda clans, traditional occupants of the southern part of the Eastern Desert in Egypt, as well as a small group of Bishari, originating from either upstream Wadi Allaqi or from the Red Sea Hills in north-eastern Sudan, settled around the lakeshore in Wadi Allaqi from the mid-1970s onwards. This population peaked at about 250 people by the early 1990s, and has now settled out at about 200-220. 
The economy that has developed comprises six main elements, five of which require careful use and management of the natural resource base. The two most important are the herding of small livestock (sheep and goats) and charcoal making, in that order of importance. Indeed, participation in these two activities is a crucial factor in household economic differentiation, in that those households that participate fully in these two activities tend to be significantly wealthier than those that do not. Thus, gender alone does not determine household roles; relative wealth is also significant. Critical to participation is access to transport, especially camels for travelling to the winter grazing and charcoal-producing areas in the Eastern Desert beyond downstream Wadi Allaqi. Poorer households have fewer such resources, and hence are excluded to a greater or lesser extent from such economic activities. Here, there is not such a clear gender division of labour, as men must work in the same spaces as women around the household.

\section{The role and potential of Bedouin women in sheep production}

At first sight, it would appear that sheep and goat production is essentially a male occupation, particularly as, now that the Bedouin communities are becoming increasingly sedentary or semisedentary, it is only the men who move with their flocks to find grazing beyond the immediate geographic area of downstream Wadi Allaqi. Winter herding of sheep and goats upstream or in the Red Sea Hills is overwhelmingly a male activity, typically involving groups of three to five men looking after flocks of up to 300 sheep and goats at a time. It is not unusual for men to be away from the settlements in Wadi Allaqi for periods of up to three months. In addition, it is men who produce and sell charcoal, and who carry out business in the towns of the Nile Valley. While these male spaces are geographically extensive, involving much of the desert and hill areas up to 200 kilometres to the east of Wadi Allaqi and the urban areas at least 180 kilometres to the north, women are spatially confined to the environment immediately around the settlements in downstream Wadi Allaqi. Men dominate the management of livestock in the expanses of the desert and the hills, but both male and female respondents insist that the management of sheep and goats around the Lake Nasser shoreline, in the areas of more permanent settlement, is predominantly a female and older child activity. Significantly, this frequently remains the case even at those times when men may be present, as during the summer months, for example. It would seem that women's responsibility for sheep and goats has increased, as the communities have become increasingly sedentarized. The absences of men from the area for varying periods of time has placed a greater onus on women to take over tasks and make short-term resource management decisions. Ill and very young sheep, and their mothers, are looked after by women in around the settlements, while a number of goats also remain more or less permanently with the women and children to supply daily milk requirements.

There are also cultural reasons for women's enthusiasm to keep sheep around the household. Sheep are not simply economic resources. The centrality of small ruminants is clear in discussions with Bedouin about their economic base, but also their sense of cultural identity. In discussions, many women clearly linked sheep ownership with wealth and security, but also considered their presence to bestow baraka, or blessing, on the household. One woman told us that if a woman has nothing but one sheep, she is still a rich woman'. Another group of women explained the importance of sheep through a tale of the Prophet Mohammed. The Prophet was fleeing men who sought to kill him when he came upon a herd of goats. He hid amidst the goats, but when his hunters arrived, the goats dispersed revealing the Prophet's hiding place. He kept running until he came upon a flock of sheep and again he tried to hide amidst the crowd of animals. This time when the men arrived, the sheep kept in tight formation around the Prophet keeping him hidden. This, we were told, demonstrated the blessing of sheep. When we spoke with one group of women (of all generations) about alternative opportunities, particularly education, they replied, rather baffled, that they did not see the point of these alternatives when, 'sheep are our lives'. Sheep are given to women at weddings and other significant occasions, again reinforcing their symbolic importance in addition to their value as measures of wealth.

Nonetheless, women's involvement in livestock production in the desert is not unproblematic. Theirs are generally animals either requiring particular care, such as pregnant, very young or sick animals, or those animals that will provide a supply of milk for the household left behind in 
downstream Wadi Allaqi. Significantly, in the context of this project, the quality of these animals is entirely dependent on local grazing resources, of which those around the lakeshore are of limited quality and abundance for much of the year. Grazing pressures experienced in the area limit the potential of women's herds. Whereas in the winter, grazing in areas away from Wadi Allaqi, men can move sheep and goats around to find ephemeral pastures, sometimes ranging over quite extensive areas, this is not an option for the women in Wadi Allaqi, as the grazing here is restricted to the more geographically constrained area of the emergent lakeshore in the area immediately around the household. It is further constrained to particular territories along the lakeshore, so as to minimize disagreements between the three main Ababda clans resident in the area. The result is that the quality and quantity of grazing in the area is somewhat limited. It is evident, therefore, that, due to women's spatial confinement to the domestic area around the lakeshore, the productivity of sheep under women's control is somewhat more limited than those grazed by men in more diverse areas. An alternative source of feed is provided by aquatic vegetation from Lake Nasser, collected from the lake shallows by women and older children. The problem with this source of feed is that it can have a deleterious effect on the health of the animals. Although it provides some dietary bulk for the livestock, the women explained that it can cause severe intestinal problems, resulting in loss of condition of the animals involved. At this point, animals are typically fed on purchased supplies of grain until their health recovers, after which their diet will once again be made up of inadequate lakeshore grazing and aquatic vegetation. The cycle starts over again. A key issue, therefore, is how the quality of sheep production in the lakeshore areas might be improved. If there is to be any meaningful success in reducing poverty amongst the poorest Bedouin groups, a key focus must be on women, as they are the main players in the sheep and goat production process in the lakeshore areas and their role in household reproduction means that improvements will have a significant effect on family health more generally (for a discussion of this relationship, see Fratkin and Smith 1995, 435).

This context of animal production - the cultural and economic importance of sheep and goats, and the limitations on their production - was discussed with the various focus groups, and what emerged was the view that a more constant and reliable supply of livestock feed could be obtained from growing fodder crops on small cultivation plots around the settlements. We spent a number of meetings with the women talking about their views on the importance of sheep and goat production in the context of the household but also for women's daily workloads, and their views on what would improve the quality of their animals. Similar conversations were carried out with male respondents. A small number of women decided to begin smallscale cultivation.

This approach seemed to follow a non-conflictual sense of empowerment in the sense of 'power to' rather than 'power over'. It did not propose the introduction of activities not already undertaken by the women but rather to find - through collaboration with the women themselves - more effective ways of doing these. There was no direct challenge to the role of Bedouin men and, indeed, the male members of the research team faced no hostility in their parallel discussions with the men at the time of this project. In Wadi Allaqi, finding and developing ways by which women could improve the quality of the sheep and goats around the household with the use of feed of a better quality would potentially contribute to a number of improvements. These include producing higher quality milk, especially from goats, resulting in improvements in children's health in particular; improving animal health generally; and creating greater stability of flock size by reducing stock losses. The overall result would be greater household security, in terms of a more secure and reliable food supply for both the Bedouin women involved and for their children. It might also provide better quality animals for sale in the market.

However, many did not embrace this opportunity for economic empowerment. There was some reluctance to spend additional time supporting sheep and goat production. It seems that there are a number of issues tied up with this reluctance, which offer an important reflection upon how 'empowerment' is to be understood in this context. Although sheep and goats are seen as important to the household economy, many women were unenthusiastic about trying to develop their role any further. In large part, this appears to be the result of the many other tasks that women have to undertake each day in maintaining the household in this challenging environment (the 'double burden' 
discussed earlier; Funk and Mueller 1993). Many Bedouin women told us that they already had a great deal to do in a day, and so did not have time to look after sheep, that they were simply too busy to spend time with the animals as men did. Women clearly felt that their share of household reproduction was high enough already. Indeed, there was a tolerance of men's forays into the hills with the sheep, seen by some as a boyish adventure that the men would enjoy. One woman said, 'let the men go to the desert and play at being boys again - we are happy to stay here [in Wadi Allaqi]'. Women had more important things to do. Further responsibility for the animals (time spent preparing land, planting, tending, watering and harvesting fodder crops) would just add a further burden to their day. There was a reluctance to adopt this additional work even given its potential cash rewards, as Bryceson (1995) might have predicted. For those women who were in families with existing sources of income i.e. men who had transport to take animals to market - there were clearly more pressing demands on time, or at least any additional time was more valued than any possible improvement to livestock quality. This view was reinforced when, during another conversation, one of the Bedouin women was spinning wool for a blanket. One of us mentioned that we had seen these being sold for a good price at the market and suggested that this would be a good source of income. The woman was clearly uninterested - she would make blankets when her family needed them and at no other time. ${ }^{4}$

There was, however, some interest, generally among poorer women, who tended to be concentrated in the Sadenab clan. Men from households in the better-off Hamedab and Fashekab clans tend to be absent more frequently and for longer periods than those from the poorer Sadenab clan. This is primarily because the latter are much less mobile, due to their lack of camels or lack of finance to secure other forms of transport, either for transhumance or for business in Aswan. Because Sadenab households own few camels between them and, as a result, are rarely able to concentrate resources to take their flocks to find grazing away from Wadi Allaqi, their entire flocks are highly dependent on the limitations of lakeshore grazing. Perhaps more than any others, these households are acutely aware of the limitations of their immediate environment, and none more so than the women of this clan. Here, where men's mobility is nearly as constrained as that of Bedouin women, their access to resources is similarly constrained to their immediate environment. In this community both men and women were more enthusiastic about the possibilities for small-scale agricultural production.

Moreover, the problem is compounded for the widows ${ }^{5}$ within the community, as they do not have menfolk to take their share of managing the livestock. Consequently, their flocks are not only smaller in size, but are also less able to be grazed and managed over wider geographic areas. Hence, it is women generally, and widows in particular, who tend to show the greatest interest in improving local conditions and providing more immediately available feed resources for their livestock. The widows we spoke with had no close male relatives to sell animals for them, or to buy feed. Hence, their abilities to sell or improve livestock are much more limited. Again, evidence suggests that widows are more willing to get involved with selling various items, to visitors or to other Bedouin women.

Those women who choose to adopt agricultural practices are thus the poorer and most marginal members of the community. It became clear from discussions that those women who choose to participate in cultivation, either producing food crops for direct family consumption or feed crops for livestock consumption, are not always perceived by the rest of the community - or even in their own self-image - as necessarily being empowered. As this was a change that was forced upon them by circumstance, rather than an innovation that could be chosen, it did not result in a feeling of empowerment. Rather, due to their lack of alternatives, because of not being able to take flocks to alternative grazing away from Wadi Allaqi, or not having male family members, for example, these women are seen as turning to cultivation as an action of last resort, and not as some emancipatory act.

\section{Women and livestock marketing in Upper Egypt}

Bedouin women do not go to the markets (indeed, most rarely visit the nearest city, Aswan, for any reason), and so none are in a position to sell sheep themselves. An otherwise quite assertive and independent Sadenab widow took the view that, although it is quite right for women to own and look after their own sheep, it is very much a man's responsibility to sell them on her behalf. For Bedouin women, therefore, their only option is for male relatives in Wadi Allaqi to sell sheep for 
them, or, failing this, for male relatives in Aswan to do this for them. For those Ababda widows with no male relatives at all, there is no alternative but to sell their sheep through 'trustworthy men', who may be either neighbours or valued family friends.

In Upper Egypt, as with sheep- and goat-herding in Bedouin communities, it appears on initial sight that the market is very much a male space, and particularly so for selling livestock. The views of Daraw livestock traders on women selling livestock are mixed to say the least, and frequently contain strong opinions. One man expressed the view that it is impossible for women to sell livestock. Other male traders, in both the local Thursday livestock market in Aswan, and the regional livestock market in Daraw, were firmly of the view that women needed a male relative, or another man, to sell for them, insisting that it is shameful for women to sell livestock.

However, the situation is not as clear as this might imply. Although no Bedouin women are involved in trade at any of the markets, other nonBedouin women, predominantly from the Nile Valley, do sell livestock. In particular, widows sell animals in both the local and regional livestock markets. Their patterns of marketing are different from men, however, perhaps a reason that their participation is sometimes overlooked. On the whole, women come to the markets rather earlier than the majority of male traders. Indeed, it is common to find that before 8 am there are more women selling sheep than later in the morning, at 11 am or noon. In the Aswan Thursday market there were sometimes as many as 12-15 women selling when the market first opened, but by late morning all had left. There are also more women involved during the peak market seasons, such as around the festival times. Consumer demand for sheepmeat increases significantly during feast periods and celebrations, and especially so at Eid el Adha (the 'big feast'), Eid el Mowled el Shareef (birth of the prophet), Eid el Fitr (that marks the end of Ramadan) and at the Christian festival of Marry Gergas. During these celebrations, it is traditional for families to consume sheep meat. Prices for animals at the Daraw and Aswan markets can more than double during the lead-up to feast times. Clearly, these periods represent premium times for selling animals, as financial returns are maximized at these particular times of year.

Women's use of the space of the market is distinctive. Unlike male traders, who tend to spread themselves out around the market, frequently standing and talking, shouting and joking with each other and prospective purchasers, women sellers tend to congregate in only one area, sitting quietly with typically small herds waiting to make a sale. At Daraw, which is a much larger and more clearly regulated livestock market than that in Aswan, those women who were selling were mostly outside the fence which enclosed the official market area. There is a charge levied for each head of livestock taken into the formal space of the market. Given their economically more marginal status, women who go to Daraw to sell stock are unlikely to be able to afford this tariff and so are generally found outside. Women traders, therefore, tend to be found rather more in the informal, less regulated spaces of the market.

Unlike men, many of whom bring animals from their own flocks, women either bring a small number of animals (generally fewer than six) of their own to sell; or they buy sheep and goats at relatively low prices early in the day. These are then re-sold in the market later in the morning for a few extra (Egyptian) pounds. This second option allows those women who have little initial capital to make a modest income over the course of the morning. Another strategy adopted by women traders is to buy animals early in the day, for the same price reasons as above, but, rather than selling them that day, they take the sheep home to fatten them for a few weeks. They then return to the market to sell them at a later date, ideally at times of inflated prices such as feast times. One such widow at Daraw market, for example, had purchased five young bishari (desert) sheep in early November, fed them up for about a month at her home, and then returned to the market to sell them, hoping to make a profit. She had intended to keep them until the feast to mark the end of Ramadan, Eid el Fitr, in late December 2000, but because she needed money before then, she was left with no choice but to sell them in early December.

The generally held view among market women is that more women trade now than in the past. One interpretation of this emergence of women in the marketplace might be that they are becoming increasingly empowered to take a fuller part in the livestock economy. Indeed, as illustrated above, women are using deliberate strategies to enter this sector. However, on talking with the women involved, it became clear that this view was rather different from their own interpretations. Rather 
than this being an empowering move, they regarded it as disempowering: they felt they should be at home in their 'proper place', that selling livestock was hard work for women, and hence something they would much rather not do. A widow at Daraw complained that she had to go to market herself to sell her own sheep, even though she would have much preferred not to. Indeed, the women we spoke to at the markets were generally widows and certainly all poor; in other words, women who have no alternative but to come and sell.

Although both men and women travel to the market to sell, their manner and actions suggest that it represents a very different cultural experience for each. The women's temporal and spatial strategies identify them as outsiders. They are not regular market traders but adopt this as a strategy when it makes most sense. Their use of space similarly identifies them as passing visitors to the market who have other things to do in addition to trade. This is supported by the manner in which women use the space of the market. Whereas for men it is clearly a place to spend the day, to drink tea and exchange information, the women appear to view it as much less of a social space. They sit quietly rather than talking and moving around. In addition, they turn up earlier and leave earlier, suggesting pressing work elsewhere.

\section{GAD and empowerment}

GAD projects recognize the complexity of change, particularly that day-to-day practical issues of survival, food production and hygiene occur at one level, but, at another, there are also the very real goals of empowering women. GAD recognizes the distinction and, sometimes, tensions that exist between immediate material needs and the longerterm transformation of unequal gender relations. It also pursues the dual goals of improving women's immediate situations and of encouraging longterm empowerment and change in gender relations. There is, however, a tension between the strategic, but politically difficult, aims of empowerment, to strengthen women's position within society, and the more immediate aims of survival, which may not have any impact at all on gender relations in society:

Strategic gender needs are those needs which are formulated from the analysis of women's subordination to men ... In contrast, practical gender needs are those needs which are formulated from the concrete conditions women experience, in their engendered position within the sexual division of labor, and deriving out of this their practical gender interests for human survival. Unlike strategic gender needs they are formulated directly by women in these positions, rather than through external interventions. (Moser 1989, 1803, emphasis in original; see also Moser 1993; Molyneux 1985)

The GAD project discussed here had both practical and strategic gender aims. The practical aims, decided in conversation with the women themselves, involved direct material ways women could produce a reliable supply of livestock feed (with grain, pumps and hoses). Information gathered in the markets could be used to inform Bedouin women about the ways in which animal prices could be maximized, including best times to sell and the best feed to produce premium prices. Strategic gender aims are assumed to emerge from the empowerment of individual women to make a greater contribution to the household economy. This, however, sees women in isolation from the household, as a separate group from the household as a whole. It therefore misses the construction of gender as a relational identity, in other words, as an identity always tied up with family gender roles and Bedouin cultural expectations of men and women. Furthermore, there are important differences in gender relations even at the local level, here within Wadi Allaqi. Other elements of the women's identities alter their gendered subjectivities (see McDowell 1992). The effects of relative wealth especially are transformative of the relationships between men and women in the household, and thus what women perceive to be in their best interest.

It is only those women who have no close male relatives who can undertake tasks designated as male, or those women whose entire family is limited by poverty to a dependence on the immediate environment, who show an interest in these activities. Widows have far less security and therefore generally see the production of sheep and goats as a way of sustaining themselves. They are also more likely to engage in cultivation. Women with husbands have access to a greater range of economic output (for example, sheep, goats, camels, charcoal, medicinal herbs, income from wage-labour by men, etc.), much of which is dependent on access to the wider desert beyond downstream Wadi Allaqi, the very thing that is much more clearly defined as a male geographic space. Widows are excluded from this world, unless they have a male relative who may be willing to take some of her 
sheep with his own flock to access winter grazing in the hills. It would appear, therefore, that it is the poorer women who are likely to be more positive towards embracing changes that may contribute to improving sheep productivity. However, while this may increase their economic security, it will not necessarily enhance their sense of empowerment, as this is a change that circumstances have forced them to take. Kabeer $(1999,436)$ defines disempowerment as the denial of choice. Thus, to be empowered means to be able to make a choice in a situation where there is the possibility of choosing otherwise. The poverty of the widows and the Sadenab leaves them with little choice in economic decisionmaking. Others in the community are unlikely to regard these women as role models thus neither the individual nor collective sense of women's activities and potentials is likely to be challenged by this process in the short run at least.

Furthermore, women already shoulder a heavy work burden and the implications of the discussions we had with them regarding animal quality would only add to this workload. This underscores the importance of discussing changes with men to ensure that it is not the women alone who must shoulder the responsibility of change. Wealthier women, or at least women with access to a greater range of economic output through marriage, appear to be less positive. Similarly, only those households which have no other source of income, or which lack men of a working age, are forced to send womenfolk into the market place to sell sheep and goats. Those women whose family situation gave them sufficient economic support seem quite happy to leave this activity to men, and to concentrate their efforts on other household reproduction activities. The long-term aims of GAD, of empowerment of women and the generation of more equitable gender relations, are not guaranteed, however successful the economic aims of the project may be.

For the Bedouin women and female traders we spoke with, at present, empowerment clearly emerges from their 'proper' roles as women in the household. Women from wealthier households appear to feel empowered through having a clear and real choice whether or not to engage in further activities (for a different example of this, see Robson 2000). Indeed, women in the marketplace clearly articulate the idea that they would prefer to have the choice not to come to the market and sell livestock, and instead to remain in the household space. The cultural security in their identity as 'good women' is clearly of more significance than the benefits offered at the marketplace, except in the case of those whose economic situation leaves them no alternative. Changes to this will have to come from women's own analysis and critique of their position in society and cannot be imposed by those from outside. This leaves the GAD project with a difficult dilemma.

GAD insists upon cultural sensitivity and many feminists are very wary of being perceived as pushing Western feminist ideals onto others. Some in the West have become reluctant to get involved in research in the Third World for fear of unduly influencing others, or for hastening processes of globalization which, some have argued, are weakening local difference (Radcliffe 1994). This should not, however, preclude discussions with Bedouin women that might illustrate other ways of being for women (as, indeed the very presence of the female Egyptian and UK GAD team members does). To avoid such discussion assumes that Bedouin culture, and women's roles in reproducing it, is timeless and unchanging. Yet it is clearly dynamic, responding to both environmental changes and to contact with a number of other groups. Most important to the Bedouin in the Eastern Desert has been a traditionally close relationship with Nubian women from the Nile Valley. ${ }^{6}$ For instance, when talking to Bedouin women about the cultural taboo on women milking sheep and goats, we were told that, although Nubian women could milk, Bedouin women were not able to - 'yet'. The indication of potential change is clear in this self-reflexive statement, which has been able to emerge through long-term contact with Nubian communities and experience of the gender relations characteristic of them.

The sense of change is much clearer in the urban areas where the monetary economy is dominant. Here women are able to operate in the market, and apparently are doing so in ever greater numbers, an activity which no Bedouin women would currently expect. The cultural notions of what 'a proper woman' should do are still strong, but women are increasingly having to adopt survival strategies to raise money to support themselves, and in the absence of male relatives, this means that they have to enter the public sphere of work.

These ideas of 'proper' behaviour illustrate well Kandiyoti's (1988) ideas about the 'patriarchal bargain', wherein women operate within a set of 
accepted constraints in their relationship with men. This idea of a 'patriarchal bargain' represents an approach that attempts to view women as active agents who are nevertheless constrained by the effects of a patriarchal system (although Kandiyoti (1998) recently argued that the concept needs to recognize more fully the context-dependency of women's positionality). In the context of North African Islamic societies, women's acceptance of constraints on their activity is 'their half of this particular patriarchal bargain - protection in exchange for submissiveness and propriety' (Kandiyoti 1988, 283). With relative wealth, women are withdrawn from non-domestic work in keeping with more respectable domestic roles, even if this means that the household will decrease its potential income. For those who are forced into the marketplace by economic necessity, it is all the more important to intensify what Kandiyoti $(1988,283)$ calls traditional modesty markers' (such as veiling, or in the case mentioned here, quiet and unassuming behaviour in the livestock market) in order to emulate as best as possible the roles expected of women in this patriarchal society. This situation is open to change, particularly with increasing market penetration to all aspects of productive life; however, ironically, as in the examples offered in this study, women themselves may be reluctant to take up these opportunities because of a lack of viable or empowering alternatives:

This is not just because of 'false consciousness' as is frequently supposed - although this can be a factor but because such changes realized in piecemeal fashion could threaten the short-term practical interests of some women, or entail a cost in the loss of forms of protection that are not compensated for in some way. (Molyneux, quoted in Kandiyoti 1988, 282)

Thus, although women's roles and identities in any 'patriarchal bargain' are shaped through conscious and quite strategic understandings of their potentials, due to the influence of socialization processes, women's own self-image is also constructed through these ideas of gender, so shaping their unconscious actions too. The empowerment they receive from the 'patriarchal bargain', and the sense of identity and security that this provides, clearly offers more than any potential improvements more radical changes might offer at present. It will only be when the women themselves decide that the benefits of change outweigh the status quo that any changes will represent empowerment rather than an act of last resort.

\section{Conclusion}

This complexity of the concept of 'empowerment' and many of the women's apparent desire to collude with the structures that oppress them can be frustrating for GAD work. It illustrates perfectly the 'entanglements of power' that complicate stories of domination and resistance, making complex any interventions intended to empower those who are marginalized by current conditions (Sharp et al. 2000). However, this is only the case if men are seen, uniformly, as 'the enemy', as powerful and always dominant. This ignores the role of men as husbands, brothers and sons, relationships that involve love and respect as well as power (Cornwall 2000). It also ignores the informal methods through which women can exert influence in these relationships. Moreover, in certain societies, there are other ways of understanding the roles of different people within communities. In some societies, women may not have a clear sense of their own interests as something separate from the family unit. In Islamic societies, for instance, rather than understanding women's empowerment as an achievement of equality with men, the two sexes are regarded as gaining equality through a complementarity: men and women's contribution and strengths are different, but should be equally valued (Karam 2000; Zuhur 1992). The individual woman is not at the centre of these feminist concerns. Women make strategic choices depending upon questions of economy and status, but also involving cultural and personal issues. GAD projects can succeed with their practical gender aims of strengthening women's roles in household production, but the strategic aims will only emerge as women themselves see them as compatible with their other roles.

\section{Acknowledgements}

The research for this paper was funded through the UK Department for International Development Gender and Development (DFID) Small Projects scheme. We would like to thank Professor Ahmed Belal for his continuing support in Aswan, and the British Council and DFID for their financial and logistical support for the Aswan-Glasgow Academic Link, without which this study could not have been undertaken. Thanks to Mike Shand of the Cartographics Unit, Department of Geography and Geomatics, University of Glasgow for producing 
Figure 1. We would also like to thank members of the Human Geography Research Group at the University of Glasgow, Sylvia Chant and an anonymous reviewer for their very thoughtful and challenging engagements with earlier versions of this paper. Most importantly though, we acknowledge the Bedouin of Wadi Allaqi who generously gave us their time over the course of this study.

\section{Notes}

1 The term 'strategy' suggests a conscious decision to agree to a 'patriarchal bargain'. However, the extent to which women collude as a conscious act or as a result of their internalization of the values which oppress them is open to debate (see Kandiyoti 1998).

2 Due to the shallow incline of Wadi Allaqi, on average fluctuations in water height in metres alter the shoreline by approximately the equivalent number of kilometres (Springuel 1997).

3 Although there are anthropological studies of settled Bedouin in the north of Egypt (e.g. Abu-Lughod 1986), there is little work on the Bedouin of the Eastern Desert of Upper Egypt, and what there is does not analyse the role of gender relations (e.g. Hobbs 1989).

4 There is evidence of the beginnings of change here as some Bedouin women and girls living close to the road to Aswan have recently begun to produce small quantities of jewellery and mats for sale to people passing through the area. At present this is not a significant departure for the women involved.

5 In Islamic societies such as this, widows are generally looked after by extended family members and it is divorced women who represent the main marginalized figures. We are not aware of any divorcees amongst the Bedouin communities we visited, while the widows we spoke to had no relatives in the desert to whom they could turn.

6 Many of the Bedouin gave Hoda a particularly warm welcome once she told them that she is Nubian. Initial conversations revolved around older Bedouin women's memories of working with Nubians before the construction of the Aswan High Dam, which, due to flooding, displaced the Nubian farmers to locations much further north in the Nile Valley.

\section{References}

Abu-Lughod L 1986 Veiled sentiments University of California Press, Berkeley CA

Briggs J 1995 Environmental resources: their use and management by the Bedouin of the Nubian Desert of southern Egypt in Binns T ed People and environment in Africa John Wiley, Chichester 61-7

Briggs J, Dickinson G, Murphy K, Pulford I, Belal A E, Moalla S, Springuel I, Ghabbour S I and Mekki A M
1993 Sustainable development and resource management in marginal environments: natural resources and their use in the Wadi Allaqi region of Egypt Applied Geography 13 259-84

Bryceson D 1995 Women wielding the hoe Oxford, BERG

Chant S and Gutmann M 2000 Mainstreaming men into gender and development: debates, reflections and experiences Oxford, Oxfam Working Papers

Cornwall A 2000 Missing men? Reflections on men, masculinities and gender in GAD IDS Bulletin 31 18-27

Einhorn B 1993 Cinderella goes to market: citizenship, gender and women's movements in East Central Europe Verso, New York

Foucault M 1977 Discipline and punish: the birth of the prison Pantheon Books, New York

Foucault M 1980 Power/knowledge Harvester Wheatsheaf, London

Fratkin E and Smith K 1995 Women's changing economic roles with pastoral sedentarization: varying strategies in alternate Rendille communities Human Ecology 23 433-54

Funk N and Mueller M eds 1993 Gender politics and postCommunism: reflections from Eastern Europe and the former Soviet Union Routledge, New York

Grown C, Elson D and Cagatay N 2000 Introduction World Development 28 1145-56

Hobbs J 1989 Bedouin life in the Egyptian wilderness American University in Cairo Press, Cairo

Jankowska H 1991 Abortion, church and politics in Poland Feminist Review 39 174-81

Kabeer N 1999 Resources, agency, achievements: reflections on the measurement of women's empowerment Development and Change 30 435-64

Kandiyoti D 1988 Bargaining with patriarchy Gender and Society 2 274-90

Kandiyoti D 1998 Gender, power and contestation: 'Rethinking bargaining with patriarchy' in Jackson C and Pearson $\mathbf{R}$ eds Feminist visions of development: gender analysis and policy Routledge, London 135-51

Karam A 2000 Feminisms and Islamisms in Egypt: between globalisation and postmodernism in Marchand $\mathbf{M}$ and Runyan A S eds Gender and global restructuring Routledge, London 194-208

Kent S 1995 Does sedentarization promote gender inequality? A case study from the Kalahari Journal of the Royal Anthropological Institute 1 513-36

Leys C 1996 The rise and fall of development theory James Currey, Oxford

Lukes S 1974 Power: a radical view Macmillan, London

McDowell L 1992 Space, place and gender relations: part 2. Identity, difference, feminist geometries and geographies Progress in Human Geography 17 305-18

Mohanty C 1988 Under Western eyes: feminist scholarship and colonial discourses Feminist Review 30 61-88

Mohanty C, Russo A and Torres L eds 1991 Third world women and the politics of feminism Indiana University Press, Bloomington IN

Molyneux M 1985 Mobilization without emancipation? 
Women's interests, state and revolution in Nicaragua Feminist Studies 11 227-54

Moser C 1989 Gender planning in the Third World: meeting practical and strategic gender needs World Development 17 1799-825

Moser C 1993 Introduction in Moser C Gender planning and development: theory, practice and training Routledge, New York 1-11

Parpart J 2002 Gender and empowerment: new thoughts, new approaches in Desai $\mathbf{V}$ and Potter $\mathbf{R}$ eds The companion to development studies Arnold, London 338-42

Peake L 1999 Empowerment in McDowell L and Sharp J eds A feminist glossary of human geography Arnold, London

Pearson R and Jackson C 1998 Introduction: interrogating development: feminism, gender and policy in Jackson C and Pearson R eds Feminist visions of development: gender analysis and policy Routledge, London 1-16

Radcliffe S 1994 (Representing) post-colonial women: authority, difference and feminisms Area 26 25-32
Rathgeber E 1995 Gender and development in action in Marchand $\mathbf{M}$ and Parpart J eds Feminism/Postmodernism/ Development Routledge, New York 204-20

Robson E 2000 Wife seclusion and the spatial praxis of gender ideology in Nigerian Hausaland Gender, Place and Culture 7 179-99

Rowlands J 1997 Questioning empowerment: working with women in Honduras London, Oxfam

Sharp J, Routledge P, Philo C and Paddison R 2000 Introduction in Sharp J, Routledge P, Philo $C$ and Paddison $\mathbf{R}$ eds Entanglements of power: geographies of domination/resistance Routledge, London 1-42

Springuel I 1997 Vegetation, land use and conservation in the south eastern desert of Egypt in Barakat $\mathbf{H}$ and Hegazy A eds Reviews in ecology: desert conservation and development Metropole, Cairo 177-206

Zuhur S 1992 Revealing reveiling: Islamist gender ideology in contemporary Egypt State University of New York Press, Albany NY 